\title{
Holsteinization results of Russian Black Pied cattle
}

\author{
O.V. Gorelik ${ }^{1, *}$, O.P. Neverova ${ }^{1}, A . K$. Zharkenov $^{2}$, and $Y u . Y u$. Zharkenova $^{2}$ \\ ${ }^{1}$ Ural State Agricultural University, 42 Karl Liebknecht str., Yekaterinburg, 620075, Russian \\ Federation \\ ${ }^{2}$ Kostanay Industrial Pedagogical College, Kostanay, 110000, Kazakhstan
}

\begin{abstract}
Holsteinized Russian Black Pied cattle of the Ural type are bred in the Sverdlovsk region, which is represented by large, highly productive animals with a high genetic potential for productivity. The aim of the study was study holsteinization results of Russian Black Pied cattle in one of the pedigree reproducers of the Sverdlovsk region. Over the past 20 years, there have been significant changes in the rearing heifers' raising intensity; their live weight at the first insemination increased and their age decreased. In terms of live weight at the first insemination, there was an increase from 2006 to 2013 to over $400 \mathrm{~kg}$; then, when switching to early insemination terms, there was a decrease in live weight to $390 \mathrm{~kg}$. The age of first insemination has decreased since 2000 from 20.2 months to 14.4 months in 2018. An inversely proportional dependence of the milk yield of first heifers on the age of the rearing heifers' first insemination has been established. An increase in milk yield occurs with a decrease in the age of the first insemination and vice versa, an increase in the age of heifers' first insemination is observed with a decrease in milk yield. Moreover, this also happened when raising both hybrid heifers and heifers of the new Ural type of Holsteinized Russian Black Pied cattle.
\end{abstract}

\section{Introduction}

Sustainable supply of the population with high-quality nutritious food, including milk, is the main necessity in ensuring the health of the nation and food security of any country [1-7]. At the same time, special attention is paid to the dairy cattle breeding development, since the main amount of more than $97 \%$ of the total production of a valuable food product and raw material for the dairy industry - milk, is obtained from cattle. Increasing cow productivity is inseparably associated with milk quality improvement [8-18]. A possible increase in milk production is ensured using highly productive livestock and the production organization, which consists of mandatory technological processes associated with reproduction, feeding, keeping and milking. The main livestock of dairy cattle is currently represented by the Russian Black Pied cattle and related breeds, including the Holstein breed having Dutch cattle roots. In recent years, the world gene pool of the best stud bulls of the Holstein breed has been widely used to improve domestic dairy cattle. Long-term holsteinization led to the

\footnotetext{
* Corresponding author: olgao205en@yandex.ru
} 
creation of a large holsteinized cattle array in various climatic and ecological-forage zones, which differs in economically useful and biological characteristics due to the cattle breed resources in the breeding zone and the origin country of stud bulls involved in crossing [1921]. So, in the Sverdlovsk region, the Russian Black Pied cattle breeding stock of the Ural offspring was inseminated with Holstein breed stud bulls' seed of Canadian, Danish and German selection. As a result, large, highly productive animals with a high genetic productivity potential and well adapted to industrial milk production were obtained. They are able to show good average daily milk yield during the entire lactation, to produce for a long time without a sharp decrease in milk yield; however, a decrease in reproductive capacity is noted [22-27]. Holsteinization results' evaluation of Russian Black Pied cattle on the milk productivity of first heifers and the growth intensity of rearing heifers is relevant and of practical importance.

The aim of the study was study holsteinization results of Russian Black Pied cattle in one of the pedigree reproducers of the Sverdlovsk region.

\section{Materials and methods}

The studies were carried out under the conditions of one of the pedigree reproducers for breeding holsteinized Russian Black Pied cattle of the Ural type. For the analysis, the data of zootechnical and pedigree registration of the Seleks base were used. The first heifers' milk productivity was considered by year by carrying out control milking once a month; quality indicators of milk were MFF and MFP in milk, which were checked monthly from each cow in the conditions of the OJSC "Uralplemcenter" dairy laboratory of the Sverdlovsk region. The raising intensity of rearing heifers was assessed in terms of live weight and age of the first insemination. Live weight was assessed by individual weighing.

\section{Results and Discussion}

The farm is engaged in breeding highly productive holsteinized Russian Black Pied cattle of the Ural type with a high thorough-bredness proportion of Holstein breed (more than 91\%). The history of the herd's creation begins in 1947. The herd stocking was carried out by purchasing livestock from the local population, as well as by importing purebred and crossbred Tagil cattle from the pedigree and commercial farms of the Nizhny Tagil state breeding nursery of Tagil cattle. For the herd reproduction at this time, both purebred Tagil and purebred Russian Black Pied stud bulls were used. Since 1981, as part of a new Ural holsteinized cattle type creation, purebred Holstein stud bulls have been used in the herd. By 1991, only $37.3 \%$ remained in the genealogical structure of Russian Black Pied dams' herd, the rest of the livestock were descendants of Holstein studs. After another 10 years, not a single animal of the Ural offspring of Russian Black Pied cattle remained in the herd. In recent years, the best Holstein bulls of the USA, Canada and Western Europe selection have been used.

The change in the genotype led to an increase in the raising intensity of rearing stocks and an increase in their age and live weight at the first insemination (fig. 1). 


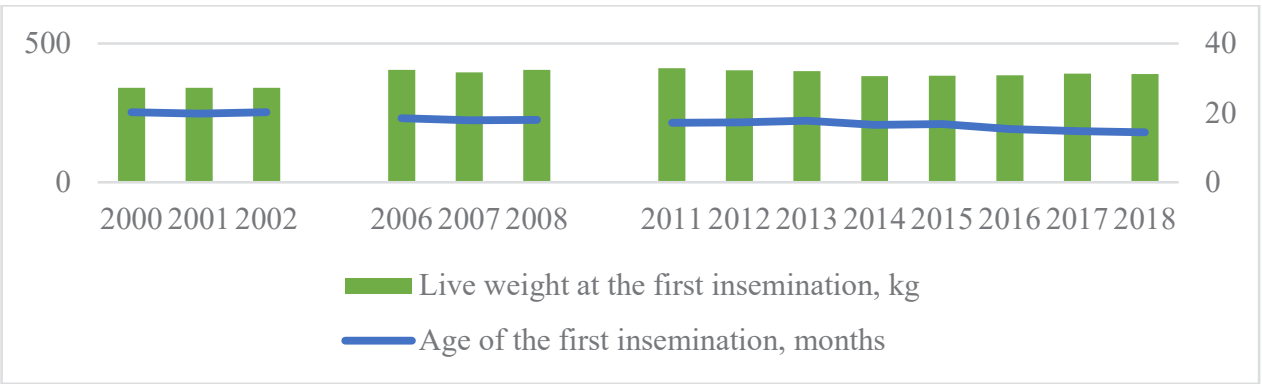

Fig. 1. Live weight and age of the first insemination of heifers by year.

Over the past 20 years, there have been significant changes in the rearing heifers' raising intensity; their live weight at the first insemination increased and their age decreased. Since the Ural type of Holsteinized Russian Black Pied cattle was officially registered only in 2002, it can be said that in 2000-2002, animals of the Russian Black Pied cattle of the Ural offspring acted as rearing heifers, which were inferior in live weight to animals of the new Ural type and, accordingly, had lower indicators in these years. In terms of live weight at the first insemination, there was an increase from 2006 to 2013 to over $400 \mathrm{~kg}$; then, when switching to early insemination terms, there was a decrease in live weight to $390 \mathrm{~kg}$. The age of first insemination has decreased since 2000 from 20.2 months to 14.4 months in 2018 .

The main breeding value indicator of dairy cattle is their milk productivity. Figure 2 presents data on first heifers' milk yield by year.

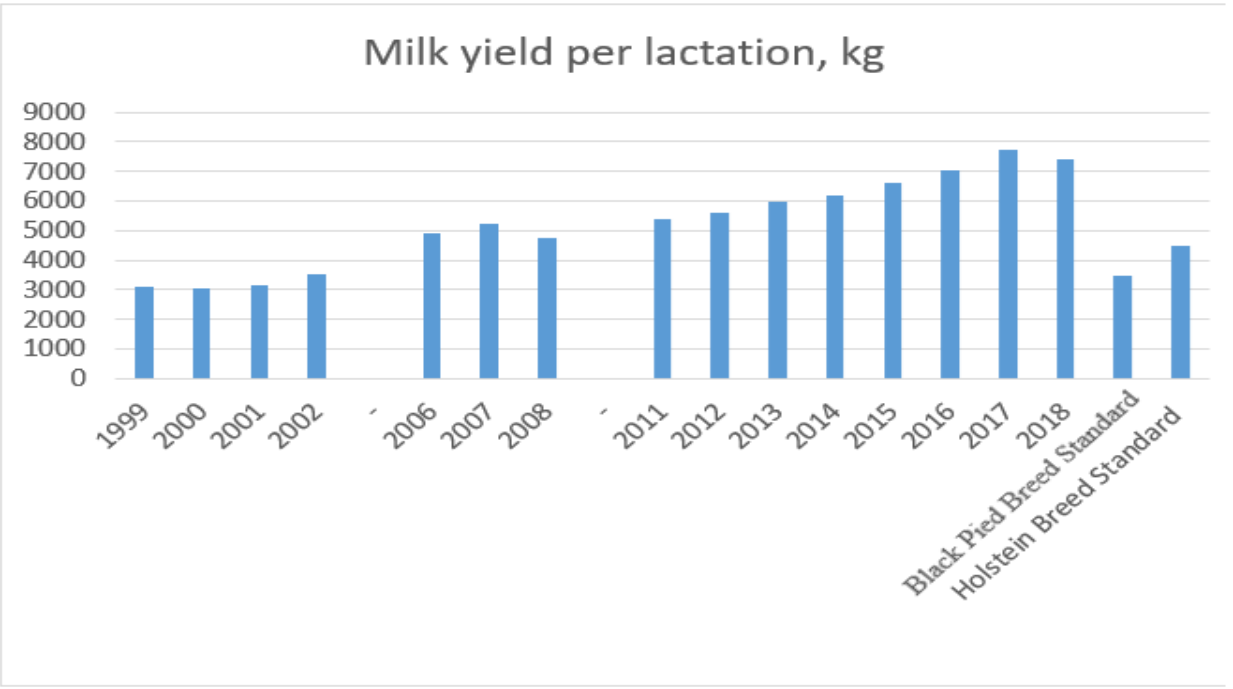

Fig. 2. Milk yield for lactation by year, kg.

During the study period since 1999, there was an increase in milk yield per lactation from $3116 \mathrm{~kg}$ to $7724 \mathrm{~kg}$ in 2017. In 2018, there was a slight decrease in milk yield per lactation by $295 \mathrm{~kg}$ or $3.8 \%$. The difference is not reliable. Greater productivity gains have been obtained since 2011. During this period, the milk yield of first heifers increased by $2064 \mathrm{~kg}$ or by $27.8 \%$, that is, by $295 \mathrm{~kg}$ per year $(4.0 \%)$, while from 1999 to 2011 , this increase amounted to $2249 \mathrm{~kg}$ or $173 \mathrm{~kg}$ per year (3.2\%).

Milk productivity of cows is also assessed by the quality indicators of milk - MFF and MFP in milk (figure 3). 


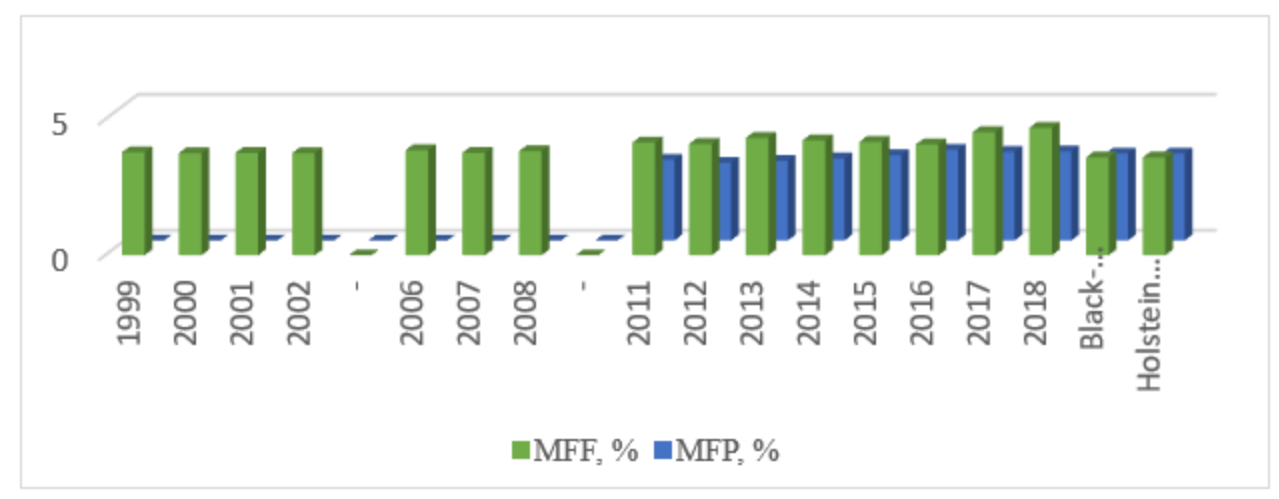

Fig. 3. MFF and MFP in cow milk by year, \%.

There was an improvement in the milk quality in terms of an increase in MFF and MFP. The MFF in milk increased from $3.76 \%$ to $4.69 \%$, or $0.93 \%$, and the MFP by $0.31 \%$.

The influence of rearing heifers' growing intensity on their future productivity is of interest. An inversely proportional dependence of the milk yield of first heifers on the age of the rearing heifers' first insemination has been established. An increase in milk yield occurs with a decrease in the age of the first insemination and vice versa, an increase in the age of heifers' first insemination is observed with a decrease in milk yield. Moreover, this happened when raising both hybrid heifers and heifers of the new Ural type of Holsteinized Russian Black Pied cattle (figure 4).

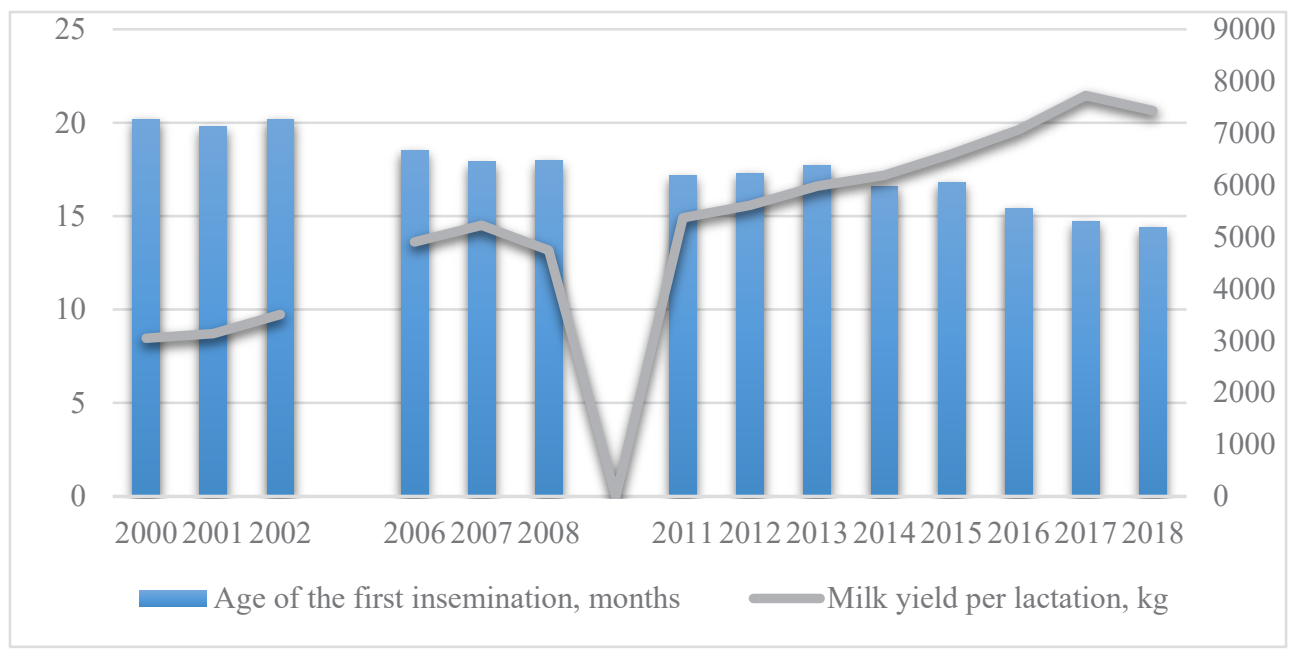

Fig. 4. Milk yield for first heifers' lactation and age of first insemination.

The transition to the technology of intensive rearing stock raising has an indirect positive effect on the productive qualities of the breeding stock introduced into the herd. Such data are confirmed by the studies of the following authors - N.V. Bogolyubova, V.P. Korotky, A.S. Zenkin, V.A. Ryzhov, N.P. Buryakov [23,24], Mymrin V and Loretts O [21], O V Gorelik, O E Lihodeevskaya, N N Zezin, M Ya Sevostyanov and O I Leshonok [25-27]. 


\section{Conclusion}

Based on the foregoing, it can be concluded that the farm uses large, highly productive holsteinized Russian Black Pied cattle of the Ural type. The genetic potential of the breeding stock productivity increases with the thorough-bredness increase in the Holstein breed. The transition to the technology of intensive rearing stock raising has a positive effect on the productive qualities of the breeding stock introduced into the herd.

\section{References}

1. O. Gorelik, M. Rebezov, A. Gorelik, S. Harlap, I. Dolmatova, T. Zaitseva, N. Maksimuk, N. Fedoseeva and N. Novikova, International Journal of Innovative Technology and Exploring Engineering, 8(7), 559-62 (2019)

2. O. Gorelik et al., International Journal of Pharmaceutical Research (2019) Doi: 10.31838/ijpr/2019.11.01.133

3. O. Gorelik et al., Annual Research \& Review in Biology, 18(4), 1-5 (2017) DOI: 10.9734/ARRB/2017/36937

4. O. Gorelik et al., AIP Conference Proceedings, 2207, 020012 (2020) doi10.1063/5.0000317

5. A. Belookov, O. Belookova, V. Zhuravel, S. Gritsenko, I. Bobyleva, E. Ermolova, S. Ermolov, Y. Matrosova, M. Rebezov and E. Ponomarev, International Journal of Engineering and Advanced Technology, 8(4), 1058-61 (2019)

6. F. Khaziakhmetov et al., Growth Research Journal of Pharmaceutical, Biological and Chemical Sciences, 9(3), 866-70 (2018) WOS:000438847100113

7. F. Khaziakhmetov, A. Khabirov, M. Rebezov, A. Basharov, I. Ziangulov and E. Okuskhanova, International Journal of Veterinary Science, 7(4), 178-81 (2018)

8. A. Gorelik et al., Advances in Agricultural and Biological Sciences, 2(1), 5-12 (2016)

9. O.V. Gorelik et al., Advances in Agricultural and Biological Sciences 2(1), 27-33 (2016)

10. F. Smolnikova, Z. Moldabayeva, M. Klychkova, O. Gorelik, R. Khaybrakhmanov, I. Mironova, A. Kalimullin and G. Latypova, International Journal of Innovative Technology and Exploring Engineering, 8(7), 670-72 (2019)

11. N. Chernopolskaya, N. Gavrilova, M. Rebezov, S. Harlap, A. Nigmatyanov, G. Peshcherov, T. Bychkova, K. Vlasova and I. Karapetyan, International Journal of Pharmaceutical Research, 11(1), 545-50 (2019) DOI: 10.35940/ijrte.B3158.078219

12. N. Chernopolskaya, N. Gavrilova, M. Rebezov, I. Dolmatova, T. Zaitseva, Y. Somova, M. Babaeva, E. Ponomarev and O. Voskanyan, International Journal of Engineering and Advanced Technology, 8(4), 40-45 (2019) DOI: 10.35940/ijrte.B3158.078219

13. N. Gavrilova, N. Chernopolskaya, M. Rebezov, D. Moisejkina, I. Dolmatova, I. Mironova, G. Peshcherov, O. Gorelik and M. Derkho, International Journal of Recent Technology and Engineering, 8(2), 2718-22 (2019) DOI: 10.35940/ijrte.B3158.078219

14. N. Gavrilova, N. Chernopolskaya, M. Rebezov, E. Shchetinina, I. Suyazova, S. Safronov, V. Ivanova and E. Sultanova, Journal of Critical Reviews, 7(4), 233-36 (2020) DOI: $10.31838 /$ jer.07.04.43

15. M. Temerbayeva et al., Annual Research \& Review in Biology, 23(6), 1-7 (2018) DOI: $10.9734 / \mathrm{arrb} / 2018 / 38800$

16. M. Temerbayeva et al., Research journal of pharmaceutical biological and chemical sciences, 9(1), 291-95 (2018) 
17. A. Serikova, F. Smolnikova, M. Rebezov, E. Okuskhanova, M. Temerbayeva, O. Gorelik, S. Kharlap, Sh. Baitukenova, S. Baitukenova and Y. Tumbasova, Research Journal of Pharmaceutical, Biological and Chemical Sciences 9(4), 495-500 (2018) WOS:000438848100062

18. F. Smolnikova, S. Toleubekova, M. Temerbayeva, E. Cherkasova, O. Gorelik, S. Kharlap, M. Derkho, M. Rebezov and I. Penkova, Research Journal of Pharmaceutical, Biological and Chemical Sciences, 9(3), 1003-08 (2018) WOS:000438847100131

19. N. Kuramshina, M. Rebezov, E. Kuramshin, L. Tretyak, G. Topuria, D. Kulikov, A. Evtushenko, S. Harlap and E. Okuskhanova, International Journal of Pharmaceutical Research, 11(1), 1301-05 (2019) DOI: 10.21668/health.risk/2019.2.04.eng

20. E. Skvortsov, O. Bykova, V. Mymrin, E. Skvortsova, O. Neverova, V. Nabokov and V. Kosilov, The Turkish Online Journal of Design Art and Communication 8(SMRCHSPCL), 291-99 (2018)

21. V. Mymrin and O. Loretts, Proceedings of the International Scientific and Practical Conference (ISPC 2019) Advances in Intelligent Systems Research, 511-514 (2019)

22. S. Gridina, V. Gridin and O. Leshonok, Advances in Engineering Research, 253-256 (2018)

23. N. Bogolyubova, V. Korotky, A. Zenkin, V. Ryzhov and N. Buryakov, OnLine Journal of Biological Sciences, 17(2), 121-27 (2017)

24. N. Bogolyubova, V. Romanov, V. Korotky, V. Ryzhov and A. Zenkin, Asian Journal of Pharmaceutical and Clinical Research, 10(10), 117-20 (2017)

25. O.V. Gorelik et al., IOP Conf. Ser.: Earth Environ. Sci., 548, 082009 (2020) doi:10.1088/1755-1315/548/8/082009

26. O.V. Gorelik et al., IOP Conf. Ser.: Earth Environ. Sci. (2020) /10.1088/1755$1315 / 548 / 8 / 082013$

27. O. Gorelik et al., AIP Conference Proceedings, 2207, 020012 (2020) doi10.1063/5.0000317 